\title{
FAKTOR-FAKTOR YANG BERHUBUNGAN DENGAN PARTISIPASI MASYARAKAT DALAM PROGRAM LAMPUNG MANGROVE CENTER (LMC) DI DESA MARGASARI KECAMATAN LABUHAN MARINGGAI KABUPATEN LAMPUNG TIMUR
}

\author{
(Factors Related to Participation of Community in Program of Lampung Mangrove Center (LMC) in \\ Margasari Village of Labuhan Maringgai Sub-District, East Lampung Regency)
}

Selvi Amelia, Indah Nurmayasari, Begem Viantimala

Jurusan Agribisnis, Fakultas Pertanian,Universitas Lampung, J1. Prof. Dr. Soemantri Brodjonegoro No.1 Bandar Lampung 35145, Telp.085766724836, e-mail: indah.nurmayasari@fp.unila.ac.id

\begin{abstract}
This research aims to analyze the level of community participation and factors related to the participation of the community in Lampung Mangrove Center $(L M C)$ program in Margasari Village, Labuhan Maringgai, East Lampung Regency. The location was purposively chosen with the consideration that the activity of the center was in Margasari consisting of 12 hamlets. The research was conducted in June - August 2017. The results showed that the level of participation of most community members is included in a medium classification. Formal education level and cosmopolite characteristics relate significantly to their participation, while their age, the length of staying in the village, and their knowledge on the program do not relate to their participation.
\end{abstract}

Key words: community, participation, program LMC

\section{PENDAHULUAN}

Indonesia merupakan negara yang cukup luas, sebagian wilayahnya merupakan wilayah perairan. Wilayah perairan tidak terlepas dari wilayah pesisir. Wilayah pesisir menjadi penting karena merupakan pertemuan antara ekosistem daratan dan ekosistem lautan. Ekosistem wilayah pantai berkarakteristik unik dan khas dan merupakan wilayah yang memiliki produktivitas hayati, intensitas sifat ekologi yang dinamis serta memiliki potensi ekonomi bahkan pariwisata Salah satu kekayaan hayati pada ekosistem pesisir ini adalah hutan mangrove. Setiap daerah pesisir memerlukan hutan mangrove untuk mencegah abrasi di daerah tersebut. Hutan mangrove merupakan salah satu ekosistem alamiah yang unik dan memiliki nilai ekologis dan ekonomi yang tinggi.

Berdasarkan data ITTO (Internation Tropical Timber Organization) Asia Tenggara memiliki luas hutan mangrove mencapai 5.104.900 ha atau $33,5 \%$ dari luas hutan mangrove dunia, dan Indonesia merupakan negara terbesar di Asia Tenggara dengan luasan hutan mangrove 3.189.000 ha. Lampung merupakan salah satu provinsi di Indonesia yang memiliki ekosistem hutan mangrove dengan luas 10.533,676 ha (Ghufran dan Kordi 2012). Lampung memiliki banyak daerah pesisir dimana setiap daerah pesisir memerlukan hutan mangrove untuk mencegah abrasi di daerah tersebut.

Menurut BPS Provinsi Lampung (2015), Kabupaten Lampung Timur merupakan wilayah terluas di Provinsi Lampung, sedangkan untuk jumlah kecamatan yang dimiliki menempati posisi kedua setelah Kabupaten Lampung Tengah, Kabupaten Lampung Timur merupakan salah satu kabupaten yang memiliki wilayah pesisir yang terluas di Provinsi Lampung karena dilalui oleh garis pantai timur. Wilayah pesisir yang memiliki luas wilayah pesisir terbesar yaitu wilayah pantai timur. Wilayah pesisir yang memiliki luas wilayah pesisir terbesar yaitu wilayah pantai timur dengan luas 270.000 ha. Wilayah tersebut mencakup wilayah dari Kabupaten Lampung Selatan, Kabupaten Lampung Timur sampai dengan Kabupaten Tulang Bawang. Wilayah pantai timur atau pesisir timur melintasi Kabupaten Lampung Timur yang meliputi Kecamatan Sukadana, Way Kambas, Labuhan Maringgai, Pasir Sakti, Way Bungur, dan Way Jepara.

Salah satu kecamatan yang ada di Kecamatan Pesisir Timur yaitu Kecamatan Labuhan Maringgai. Kecamatan Labuhan Maringgai memiliki 11 desa dengan luas wilayah yang berbeda-beda. Berdasarkan Wilayah desa terluas yang ada di Kecamatan Labuhan maringgai yaitu Desa Labuhan Maringgai (3.340 ha) dan Desa 
Margasari yaitu seluas (1.702 ha). Kecamatan Labuhan Maringgai memiliki beberapa desa yang berbatasan langsung dengan pantai timur atau pesisir timur, desa tersebut memiliki hutan mangrove yang digunakan untuk menjaga terjadinya abrasi. Desa Margasari merupakan desa yang memiliki luas hutan mangrove yang paling luas. Desa margasari juga memiliki pusat kegiatan pengelolaan hutan mangrove yang disebut Lampung Mangrove Center (LMC).

LMC berdiri dilatarbelakangi terjadinya kerusakan hutan mangrove sebagai sabuk hijau (green belt) di pesisir timur Lampung yang sudah memprihatinkan. Kerusakan hutan mangrove membuat beberapa pihak khususnya masyarakat Desa Margasari dibantu oleh berbagai pihak antara lain Pemerintah Kabupaten Lampung Timur dan stakeholders yang terdiri dari Universitas Lampung dan Lembaga Swadaya Masyarakat dalam melestarikan kawasan hutan mangrove. Dari berbagai kegiatan dalam program LMC yang paling aktif dalam program ini yaitu pelatihan pendidikan mengenai ekosistem mangrove. Hal ini dikarenakan semakin lama luas tutupan hutan mangrove yang terus mengalami penurunan.

LMC berada di Desa Margasari Kecamatan Labuhan Maringgai. Desa Margasari merupakan desa yang banyak mengalami penurunan luas hutan mangrove. Program pelestarian hutan mangrove melalui kegiatan pelatihan pendidikan ekosistem mengrove yang dilakukan dalam program LMC melibatkan masyarakat yang ada di Desa Margasari.

Program LMC bertujuan untuk mewujudkan suatu sistem tata kelola wilayah pesisir secara terpadu untuk keberlanjutan pembangunan dan kesejahteraan masyarakat serta menjadi permodelan pengelolaan mangrove berskala nasional. Program LMC terdiri dari beberapa program yaitu salah satunya adalah kegiatan pelatihan pendidikan mengenai ekosistem mangrove. Menurut pendapat Murtiyanto (2011) keberhasilan pembangunan pertanian tidak terlepas dari partisipasi masyarakat, maka dari itu keberhasilan program LMC juga tidak terlepas dari partisipasi masyarakat dalam mencapai tujuan dari program LMC tersebut, Mengingat pentingnya partisipasi masyarakat dalam kegiatan pelatihan pendidikan ekosistem mangrove dalam program LMC. Terkait dengan uraian ini penulis tertarik melakukan penelitian mengenai " Bagaimana partisipasi dan faktor-faktor yang berhubungan partisipasi masyarakat dalam program Lampung
Mangrove Center di Desa Margasari Kecamatan Labuhan Maringgai Kabupaten Lampung Timur".

\section{METODE PENELITIAN}

Penelitian ini dilakukan di Desa Margasari Kecamatan Labuhan Maringgai Kabupaten Lampung Timur. Penentuan lokasi dilakukan secara sengaja (purposive). Metode penelitian yang digunakan adalah survei. Data yang digunakan dalam penelitian ini adalah data primer yang diperoleh melalui kuesioner dan pengamatan langsung di lapangan, dan data sekunder yang diperoleh dari literatur, dan lembaga/instansi yang terkait dengan penelitian.

Waktu penelitian dimulai dari saat prasurvei sampai dengan penyusunan laporan akhir, dan pengumpulan data penelitian di lapangan dilaksanakan pada bulan Juni - Agustus 2017. Populasi dalam penelitian ini adalah Kepala Keluarga di Desa Margasari yaitu sebanyak 1.859 KK yang tersebar di 12 dusun. Penentuan jumlah sampel dengan menggunakan rumus Sugiarto, dkk (2003).

$\mathrm{n}=\frac{\mathrm{NZ} \mathrm{Z}^{2} \mathrm{~S}^{2}}{\mathrm{Nd}^{2}+\mathrm{Z}^{2} \mathrm{~S}^{2}}$

Keterangan:

$\mathrm{n} \quad$ : Jumlah sampel

$\mathrm{N}$ : Jumlah populasi

$\mathrm{Z}$ : Tingkat kepercayaan $(95 \%=0,95)$

$S^{2} \quad$ : Varian sampel $(5 \%=0,05)$

D : Derajat penyimpangan $(5 \%=0,05)$

Berdasarkan rumus tersebut didapat jumlah responden yang digunakan dalam penelitian ini yaitu sebanyak 74 responden. Pengambilan sampel dilakukan dengan memberi kesempatan yang sama pada setiap anggota populasi untuk menjadi anggota sampel. jumlah sampel untuk setiap dusun dilakukan dengan metode Proportional random sampling, dihitung dengan menggunakan rumus menurut (Sugiono, 2009), yaitu:

$\mathrm{n}=\frac{\mathrm{Ni}}{\mathrm{N}} \times \mathrm{ni}$

Keterangan:

$\mathrm{n}$ : Jumlah sampel yang akan diambil pada setiap kelompok.

$\mathrm{N}$ : Jumlah total populasi pada semua kelompok.

$\mathrm{Ni}$ : Jumlah populasi pada kelompok ke (i).

ni : Jumlah sampel pada semua kelompok. 
Variabel bebas (X) dalam penelitian ini meliputi, usia, tingkat kosmopolit, pendidikan formal, lama tinggal, dan tingkat pengetahuan terhadap program. Pengukuran variabel tingkat kosmopolit dan pengetahuan terhadap program menggunakan teknik skoring dengan skor $1-3$, sedangkan untuk variabel usia, pendidikan formal, dan lama tinggal dihitung berdasarkan tahun. Pengukuran variabel (Y) yaitu tingkat partisipasi masyarakat pada ahap perencanaan pelaksanaan, evaluasi, dan pemanfaatan dalam program LMC diukur dengan teknik skoring $1-3$. Data ordinal berupa skor selanjutnya dikonversikan menjadi data interval menggunakan Method Successive Interval (MSI).

Pengolahan adalah tabulasi dan analisis data yang digunakan dalam penelitian ini adalah dengan analisis deskriftif ditujukan untuk menjelaskan tingkat partisipasi masyarakat dalam Program Lampung Mangrove Center. Pengujian hipotesis menggunakan statistik non parametrik korelasi peringkat Rank Spearman.

1. Jika $\mathrm{t}$ hitung $\leq \mathrm{t}$ tabel maka terima $\mathrm{H}_{0}$, pada $(\alpha)=0,05$ atau $(\alpha)=0,01$ berarti terdapat hubungan antara kedua variabel yang diuji.

2. Jika t hitung $>\mathrm{t}$ tabel maka tolak $\mathrm{H}_{0}$, pada $(\alpha)$ $=0,05$ atau $(\alpha)=0,01$ berarti tidak terdapat hubungan antara kedua variabel yang diuji.

\section{HASIL PENELITIAN}

\section{Karakteristik Responden}

Mata pencaharian masyarakat di Desa Margasari terdiri dari nelayan, petani, wiraswasta, dan aparat pemerintahan. Umumnya masyarakat yang ada di Desa Margasari ini bermata pencaharian sebagai nelayan hal ini dikarenakan daerah Desa Margasari yang berbatasan langsung dengan pesisir timur Provinsi Lampung yang berdampak pada potensi alam bahari yang sangat banyak yang dapat dimanfaatkan oleh masyarakatnya sendiri.

\section{Deskripsi Variabel-Variabel yang Berhubungan dengan Tingkat Partisipasi Masyarakat dalam Program Lampung Mangrove Center (LMC)}

\section{$\operatorname{Usia}\left(X_{1}\right)$}

Usia $\left(\mathrm{X}_{1}\right)$ merupakan salah satu faktor yang mempengaruhi tingkat kemampuan seseorang dalam mengelola potensi dirinya. Berdasarkan Tabel 1, diperoleh usia responden berkisar antara usia 27 - 66 tahun dan rata-rata usia responden berusia 43 tahun. Hal ini menunjukkan keadaan usia responden di Desa Margasari Kecamatan Labuhan Maringgai Kabupaten Lampung Timur termasuk dalam kategori usia produktif. Responden yang berada di usia produktif dianggap mampu dan cakap dalam melaksanakan tugas dalam kegiatan pengelolaan hutan mangrove dalam program LMC.

\section{Tingkat Kosmopolit $\left(X_{2}\right)$}

Tingkat kosmopolit adalah sifat yang menggambarkan keterbukaan masyarakat atau responden terhadap lingkungan yang berada di luar sistem sosialnya. Tingkat kosmopolit diukur berdasarkan hubungan masyarakat dengan lingkungan luar baik dengan masyarakat di luar desa maupun dengan beberapa stakeholders lainnya. Responden yang memiliki tingkat kurang kosmopolit dikarenakan responden tidak pernah melakukan interaksi dengan lingkungan luar tempat tinggalnya.

Tingkat kosmopolit responden berdasarkan keadaan di lapang termasuk dalam kategori cukup kosmopolit. Masyarakat menyatakan cukup antusias untuk melakukan kegiatan anjangsana maupun pertemuan dengan tokoh masyarakat dari desa lain, ada pula sebagian dari masyarakat yang tidak antusias dalam melakukan anjangsana, faktor lain yang menyebabkan tingkat kosmopolit berada dalam kategori cukup kosompolit masyarakat lebih memanfaatkan waktu luangnya digunakan untuk beristirahat. Tabel 2 menunjukkan bahwa tingkat kosmopolit masyarakat dalam keadaan cukup kosmopolit.

Tabel.1 Sebaran responden berdasarkan usia

\begin{tabular}{ccc}
\hline Interval (Tahun) & Jumlah (orang) & Persentase (\%) \\
\hline $27-40$ & 31 & 0 \\
$40,1-53,1$ & 39 & 100 \\
$53,2-66,2$ & 13 & 0 \\
\hline Jumlah & 74 & 100,00 \\
\hline Rata-rata :43 tahun & & \\
\hline
\end{tabular}

Tabel 2. Sebaran responden berdasarkan tingkat kosmopolit

\begin{tabular}{|c|c|c|c|}
\hline Interval (skor) & Klasifikasi & $\begin{array}{l}\text { Jumlah } \\
\text { (orang) }\end{array}$ & $\begin{array}{c}\text { Persentase } \\
(\%)\end{array}$ \\
\hline $8,340-11,299$ & $\begin{array}{l}\text { Kurang } \\
\text { Kosmopolit }\end{array}$ & 16 & 21,62 \\
\hline $11,3-14,259$ & $\begin{array}{l}\text { Cukup } \\
\text { Kosmopolit }\end{array}$ & 34 & 45,95 \\
\hline $14.26-17,219$ & Kosmopolit & 24 & 32,43 \\
\hline Jumlah & & 74 & 100,00 \\
\hline
\end{tabular}




\section{Tingkat Pendiddikan Formal $\left(X_{3}\right)$}

Tingkat pendidikan formal adalah jumlah tahun atau lamanya pendidikan formal yang diikuti oleh responden selama hidupnya. Tingkat pendidikan formal akan mempengaruhi masyarakat dalam mengadopsi teknologi, inovasi baru maupun keterampilan. Pendidikan formal selain mempengaruhi pengetahuan seseorang, biasanya mempengaruhi keaktifan partisipasi seseorang dalam setiap program.

Berdasarkan data lapang diketahui bahwa sebanyak 37 orang atau sebanyak 50\% responden memiliki jenjang pendidikan formal antara 7 sampai dengan 12 tahun, dan rata-rata responden memiliki jenjang pendidikan formal selama 9,3 tahun. Penelitian di lapangan menunjukkan sebagian besar responden LMC hanya menyelesaikan pendidikannya hingga sekolah menengah pertama (SMP).

Menurut Suroso (2014) semakin tinggi tingkat pendidikan formal masyarakat biasanya akan lebih cepat dalam mengadopsi tekonologi-teknologi baru dibandingkan dengan masyarakat yang mempunyai tingkat pendidikan yang lebih rendah. Tabel 3 menunjukkan sebaran tingkat pendidikan formal masyarakat.

\section{Lama Tinggal $\left(X_{4}\right)$}

Lama tinggal $\left(\mathrm{X}_{4}\right)$ adalah lamanya seseorang berada dalam lingkungan tertentu dan berinteraksi dengan lingkungan tersebut. Berdasarkan Tabel 5, dapat dilihat bahwa 40 responden atau sebanyak $54,05 \%$ responden di Desa Margasari sudah bermukim selama $24-40$ tahun, rata-rata responden sudah bermukim di Desa Margasari selama 37,81 tahun.

Lama tinggal juga dianggap dapat mempengaruhi seseorang dalam berpartisipasi, dimana seseorang yang lebih lama tinggal dalam suatu masyarakat akan mempunyai perasaan memiliki daerah ditinggali yang lebih besar daripada yang tinggal untuk sementara waktu saja dalam lingkungan masyarakat tersebut (Slamet 1994).

\section{Tingkat Pengetahuan tentang Program LMC $\left(X_{5}\right)$}

Tingkat pengetahuan masyarakat tentang program LMC merupakan segala sesuatu hal yang responden ketahui mengenai program Lampung Mangrove Center. Berdasarkan indikator diketahui bahwa tingkat pengetahuan responden berada pada klasifikasi cukup baik. Hal tersebut didukung dari hasil penelitian lapang yang menunjukkan bahwa sebanyak 50 orang $(67,56 \%)$ anggota memiliki tingkat pengetahuan yang cukup tentang program LMC. Responden sebanyak 18 orang $(24,32 \%)$ memiliki pengetahuan yang baik mengenai LMC seperti: pengetahuan terhadap program, tujuan program, manfaat program, dan informasi mengenai fasilitas penunjang yang diberikan (Tabel 5).

Berdasarkan hasil penelitian diperoleh gambaran tingkat pengetahuan tentang kegiatan pelatihan pendidikan ekosistem mangrove dalam program Lampung Mangrove Center di Desa Margasari berada dalam klasifikasi cukup baik hal ini menunjukan keikutsertaan masyarakat yang cukup untuk mengetahui setiap kegiatan baik itu mengenai kegiatan, tujuan kegiatan, dan manfaat kegiatan itu sendiri.

Tabel 3. Tingkat pendidikan responden program LMC di Desa Margasari Kecamatan Labuhan Maringgai Kabupaten Lampung Timur

\begin{tabular}{ccc}
\hline $\begin{array}{c}\text { Jenjang pendidikan } \\
\text { formal (tahun) }\end{array}$ & $\begin{array}{c}\text { Jumlah } \\
\text { (orang) }\end{array}$ & Persentase (\%) \\
\hline $3-7,6$ & 28 & 37,84 \\
$7,7-12,3$ & 37 & 50 \\
$12,4-17$ & 9 & 12,16 \\
\hline Jumlah & 74 & 100,00 \\
\hline Rata-rata:9,3 tahun & & \\
\hline
\end{tabular}

Tabel 4. Sebaran responden berdasarkan lama tinggal

\begin{tabular}{ccc}
\hline $\begin{array}{c}\text { Interval } \\
\text { (Tahun) }\end{array}$ & $\begin{array}{c}\text { Jumlah } \\
\text { (orang) }\end{array}$ & $\begin{array}{c}\text { Persentase } \\
(\%)\end{array}$ \\
\hline $6-23$ & 6 & 8,11 \\
$24-40$ & 40 & 54,05 \\
$41-57$ & 28 & 37,84 \\
\hline Jumlah & 74 & 100,00 \\
\hline Rata-rata: 37,81 tahun & &
\end{tabular}

Tabel 5. Tingkat pengetahuan responden tentang program LMC di Desa Margasari

\begin{tabular}{cccc}
\hline Interval (Skor) & Klasifikasi & $\begin{array}{c}\text { Jumlah } \\
\text { (orang) }\end{array}$ & $\begin{array}{c}\text { Persentase } \\
(\%)\end{array}$ \\
\hline $4,000-6,605$ & Kurang baik & 6 & 8,12 \\
$6.606-9,211$ & Cukup baik & 50 & 67,56 \\
$9,212-11,817$ & Baik & 18 & 24,32 \\
\hline Jumlah & & 74 & 100,00 \\
\hline Rata-rata $: 8,406$ (Cukup Baik) & & \\
\hline
\end{tabular}




\section{Deskripsi Variabel Partisipasi Masyarakat dalam Program LMC}

Partisipasi masyarakat dalam program LMC (Variabel Y) merupakan keikutsertaan masyarakat dalam seluruh tahapan kegiatan program LMC. Partisipasi masyarakat dilihat dari empat indikator partisipasi yang meliputi partisipasi dalam perencanaan, partisipasi dalam pelaksanaan kegiatan, partisipasi dalam evaluasi pelaksanaan program, dan partisipasi dalam menikmati hasil program dan pemanfaatannya.

\section{Partisipasi Masyarakat pada Tahap Perencanaan $\operatorname{Program}\left(Y_{1}\right)$}

Partisipasi masyarakat pada tahap perencanaan program merupakan keikutsertaan masyarakat pada tahap awal perencanaan program yang diukur berdasarkan: Mengikuti pertemuan dalam mengidentifikasi masalah yang terjadi pada program dan memberi masukan dalam perencaanan untuk memecahkan masalah dalam program LMC.

Hasil penelitian menunjukkan bahwa 34 responden masuk dalam klasifikasi sedang pada tingkat partisipasi masyarakat dalam perencanaan program LMC. artinya masyarakat sudah mempunyai kemauan yang cukup tinggi untuk ikut dalam pelaksanaan perencanaan program LMC yang meliputi kegiatan pelatihan pendidikan ekosistem mangrove. Masyarakat sudah memiliki kemauan yang cukup untuk ikut serta dalam perencanaan program karena masyarakat ingin menyampaikan pendapatnya mengenai keadaan ekosistem mangrove yang berada di lingkungan tempat tinggalnya sehingga kegiatan yang akan dicapai sesuai dengan tujuan yang masyarakat inginkan. Sebaran reponden berdasarkan tingkat partisipasi pada tahap perencanaan program dapat dilihat pada Tabel 6.

Tabel 6. Sebaran respoden berdasarkan tingkat partisipasi masyarakat pada tahap perencanaan program LMC

\begin{tabular}{lccc}
\hline Interval (Skor) & Klasifikasi & $\begin{array}{c}\text { Jumlah } \\
\text { (Orang) }\end{array}$ & $\begin{array}{c}\text { Persentase } \\
(\%)\end{array}$ \\
\hline $5,502-8,39$ & Rendah & 5 & 6,76 \\
$8,40-11,288$ & Sedang & 34 & 45,95 \\
$11,289-14,177$ & Tinggi & 35 & 47,29 \\
\hline \multicolumn{2}{c}{ Jumlah } & 74 & 100,00 \\
\hline \multicolumn{2}{l}{ Rata-rata: 10,815 (Sedang) } & & \\
\hline
\end{tabular}

Partisipasi Masyarakat pada Tahap Pelaksanaan $\left(Y_{2}\right)$

Partisipasi masyarakat pada tahap pelaksanaan adalah keikutsertaan masyarakat pada kegiatan: menentukan program yang perlu dijalankan sebagai program utama, mengikuti semua tugas dalam setiap kegiatan program, dan membantu dalam pembuatan laporan pelaksanaaan kegiatan program LMC. tingkat partisipasi masyarakat pada tahap pelaksanaan masuk data kategori sedang dengan rata-rata skor sebesar 7,900. Data hasil penelitian lapang skor terendah 4,416 dan skor tertingginya sebesar 10,169 .

Berdasarkan hasil penelitian lapang, sebanyak 42 orang dalam kategori tinggi. Hal ini menunjukkan bahwa kesadaran masyarakat untuk ikut serta dalam kegiatan pelatihan ekosistem mangrove sudah cukup tinggi, akan tetapi partisipasi rata-rata masyarakat dalam program LMC masuk dalam kategori sedang dikarenakan banyak masyarakat tidak dapat ikut serta dalam pelaksanaan karena waktu pelaksaan yang tidak sesuai dengan jadwal kegiatan masyarakat sehari-hari. Sebaran reponden berdasarkan tingkat partisipasi pada tahap perencanaan program dapat dilihat pada Tabel 7 .

\section{Partisipasi Masyarakat pada Tahap Evaluasi Pelaksanaan program $\left(Y_{3}\right)$}

Partisipasi masyarakat pada tahap evaluasi adalah keikutsertaan masyarakat dalam setiap evaluasi program. Berdasarkan Tabel 8, Partisipasi masyarakat dalam tahap evaluasi program masuk dalam kategori sedang. Masyarakat sudah sadar untuk ikut serta dalam proses evaluasi terhadap program yang sudah dijalankan untuk perbaikan kegiatan yang akan dilaksanakan pada waktu selanjutnya. Akan tetapi masih ada masyarakat yang tidak ikut serta dalam tahap evaluasi program dan ada juga masyarakat yang beranggapan bahwa kegiatan yang dilakukan tidak sesuai dengan rencana yang sudah direncanakan.

Tabel 7. Sebaran respoden berdasarkan tingkat partisipasi masyarakat pada tahap pelaksanaan

\begin{tabular}{cccc}
\hline Interval (Skor) & Klasifikasi & $\begin{array}{c}\text { Jumlah } \\
(\text { Orang) }\end{array}$ & $\begin{array}{c}\text { Persentase } \\
(\%)\end{array}$ \\
\hline $4,416-6,342$ & Rendah & 17 & 22,97 \\
$6,343-8,269$ & Sedang & 15 & 20,27 \\
$8,270-10,196$ & Tinggi & 42 & 56,76 \\
\hline Jumlah & & 74 & 100,00 \\
\hline Rata-rata: 7,900 (Sedang) & & \\
\hline
\end{tabular}


Tabel 8. Sebaran responden berdasarkan tingkat partisipasi masyarakat pada tahap evaluasi

\begin{tabular}{cccc}
\hline Interval (Skor) & Klasifikasi & $\begin{array}{c}\text { Jumlah } \\
\text { (Orang) }\end{array}$ & $\begin{array}{c}\text { Persentase } \\
(\%)\end{array}$ \\
\hline $11,203-14,035$ & Rendah & 15 & 20,27 \\
$14,036-16,868$ & Sedang & 41 & 55,41 \\
$16,869-19,699$ & Tinggi & 18 & 24,32 \\
\hline Jumlah & & 74 & 100,00 \\
\hline Rata-rata: 15,386 (Sedang) & & \\
\hline
\end{tabular}

Tabel 9. Sebaran responden berdasarkan tingkat partisipasi masyarakat pada tahap menikmati hasil dan pemanfaatannya

\begin{tabular}{cccc}
\hline Interval (Skor) & Klasifiksi & $\begin{array}{c}\text { Jumlah } \\
\text { (Orang) }\end{array}$ & $\begin{array}{c}\text { Persentase } \\
(\%)\end{array}$ \\
\hline $3.000-4,598$ & Rendah & 20 & 27,03 \\
$4,599-6,197$ & Sedang & 22 & 29,73 \\
$6,198-7,796$ & Tinggi & 32 & 43,24 \\
\hline Jumlah & & 74 & 100,00 \\
\hline Rata-rata: 5, 593 (Sedang) & & \\
\hline
\end{tabular}

Tabel 10. Sebaran responden berdasarkan tingkat partisipasi masyarakat dalam program LMC

\begin{tabular}{lccc}
\hline Interval (Skor) & Klasifikasi & $\begin{array}{c}\text { Jumlah } \\
\text { (orang) }\end{array}$ & $\begin{array}{c}\text { Persentase } \\
(\%)\end{array}$ \\
\hline $31,796-38,022$ & Rendah & 24 & 32,43 \\
$38,023-44,249$ & Sedang & 42 & 56,76 \\
$44,250-50,476$ & Tinggi & 8 & 10,81 \\
\hline Jumlah & & 74 & 100,00 \\
\hline Rata-rata 39,695 (Sedang) & & \\
\hline
\end{tabular}

Partisipasi Masyarakat pada Tahap Menikmati Hasil Program dan Pemanfaatannya $\left(Y_{4}\right)$

Partisipasi masyarakat pada tahap menikmati hasil masuk dalam kategori sedang (Tabel 9) pada tahap menikmati hasil dan pemanfaatannya. Hal ini menunjukkan bahwa masyarakat sudah ikut serta dalam menikmati hasil dan pemanfaatannya yang datang dari kegiatan pelatihan melestarikan ekosistem mangrove. Masyarakat sudah sadar hasil yang diterima selama menikmati kegiatan pelatihan ini cukup banyak seperti mendapatkan wawasan akan pentingnya melestarikan mangrove yang dapat berdampak dalam segi sosial maupun segi ekonomi.

Segi ekonomi yang didapat dari pelatihan ekosistem ini yaitu masyarakat dapat menambah pendapataan rumah tangganya dengan memanfaatkan hasil hutan mangrove, antara lain: mengambil rajungan, pemanfaatan biji mangrove yang dijadikan kripik, dan dari segi sosial terjalinnya silaturahmi yang terjadi baik dalam masyarakat di Desa Margasari itu sendiri tapi juga dengan stakeholders lainnya.

\section{Tingkat Partisipasi Masyarakat dalam Program LMC (Y)}

Berdasarkan hasil penelitian tingkat partisipasi masyarakat di Desa Margasari dalam Program LMC masuk dalam kategori sedang, artinya sebagian besar masyarakat sudah ikut serta dan berperan aktif dalam program LMC khususnya kegiatan pelatihan pendidikan ekosistem mangrove. Pencapaian tingkat partisipasi sedang dalam kegiatan ini sejalan dengan hasil penelitian Nurmayasari, Prasmatiwi, Saleh (2017) yang menyatakan bahwa anggota berpartisipasi dalam beberapa kegiatan lumbung pangan seperti dalam kegaiatan perencanaan, pelaksanaan, dan evaluasi. Dalam kegiatan LMC masyarakat aktif dalam penyampaian informasi mengenai keadaan desanya dan masyarakat juga memiliki keterbukaan dalam penerimaan informasi dari lingkungan luar dan stakeholders yang berkaitan dengan mangrove. Hal ini yang membuat masyarakat cukup berpartisipasi dalam kegiatan LMC karena masyarakat mengetahui informasi mengenai manfaat dari program LMC.

Tingkatan partisipasi dapat dikaitkan dengan teori The Arnstein Ladder tangga Arnstein dalam (Wicaksono 2010) yang menyatakan ada delapan anak tangga partisipasi yang diurutkan dari bawah ke atas, yaitu manipulation, therapy, informing, consulation, placation, patnership, delegated power dan citizen control. Berdasarkan teori yang dikemukan oleh Arnstein, partisipasi masyarakat dalam program Lampung Mangrove Center berada dalam tangga menginformasikan (informing), dengan memberi informasi kepada masyarakat tentang hak, tanggungjawab dan pilihan mereka merupakan langkah awal yang sangat penting dalam proses pelaksanaan partisipasi masyarakat.

\section{Hasil Pengujian Hipotesis}

Analisis hubungan antara variabel $\mathrm{X}$ dan variabel Y menggunakan statistik non-parametrik uji korelasi Rank Spearman dengan membandingkan t hitung dengan $\mathrm{t}$ tabel (Tabel 11). Hasil pengujian hipotesis antara Usia $\left(\mathrm{X}_{1}\right)$ dengan partispasi masyarakat dalam program LMC (Y) menunjukkan nilai $t$ hitung sebesar 0,4078 lebih kecil dibandingkan dengan nilai t tabel pada taraf kepercayaan $95 \%$ maupun pada taraf $99 \%$ atau $\alpha$ $(0,05$ dan 0,01$)$ artinya tidak terdapat hubungan 
antara usia dengan tingkat partisipasi masyarakat dalam program LMC. Usia tidak berhubungan dengan tingkat partisipasi masyarakat dalam program Lampung Mangrove Center karena semua usia responden berkelompok pada usia produktif. Hasil penelitian ini sejalan dengan hasil penelitian Antika (2017) yang menyatakan bahwa usia tidak berhubungan dengan tingkat partisipasi masyarakat dalam program. Berdasarkan hasil penelitian lapang responden berada di kisaran umur 50 tahun keatas sehingga terkait dengan tingkat pemahaman responden terhadap program, semakin tua usia responden, maka tingkat pemahaman terhadap program semakin berkurang.

Hasil pengujian hipotesis Tingkat Kosmopolit $\left(\mathrm{X}_{2}\right)$ dengan partispasi masyarakat dalam program LMC (Y) menunjukkan hubungan antara tingkat kosmopolit dengan partisipasi masyarakat dalam program LMC diperoleh nilai rank spearman $\left(\mathrm{r}_{\mathrm{s}}\right)$ yaitu sebesar 0,282 , dan didapat nilai t hitung yaitu sebesar 2,494 hal ini menunjukkan nilai t hitung lebih besar dari $\mathrm{t}$ tabel pada taraf kepercayaan $\alpha$ $(0,05$ dan 0,01$)$ artinya tingkat kosmopolit $\left(\mathrm{X}_{2}\right)$ mempunyai hubungan dengan tingkat partisipasi masyarakat dalam program LMC (Y). Masyarakat di Desa Margasari sebagian besar sudah memanfaatkan media, baik media elektronik ataupun media cetak, dan masyarakat juga menerima keterbukaan dalam penerimaan informasi dari lingkungan luar. Hasil penelitian ini sejalan dengan hasil penelitian Thania (2107) yang menyatakan tingkat kosmopolit berpengaruh terhadap tingkat partispasi masyarakat dalam program UP2PJK.

Hasil pengujian hipotesis tingkat pendidikan formal $\left(\mathrm{X}_{3}\right)$ dengan partispasi masyarakat dalam program LMC (Y) menunjukkan nilai koefisien Rank Spearman $\mathrm{r}_{\mathrm{s}}$ sebesar 0,223, dan didapat nilai $\mathrm{t}$ hitung sebesar 1,941. Hal ini menunjukkan bahwa nilai $t$ hitung lebih besar dari $t$ tabel pada taraf kepercayaan $\alpha(0,05)$ artinya tingkat pendidikan formal $\left(\mathrm{X}_{3}\right)$ mempunyai hubungan dengan tingkat partisipasi masyarakat dalam program LMC (Y). Responden yang memiliki pendidikan formal yang lebih tinggi cenderung untuk mengikuti program LMC, hal ini dikarenakan pemikiran responden tersebut sudah lebih maju untuk melestarikan hutan mangrove. Hasil Penelitian ini sejalan dengan penelitian yang dilakukan Widyanti, Gitosaputro, Yanfika (2015) yang menyatakan tingkat pendidikan formal berhubungan nyata dengan tingkat partisipasi petani.
Hasil pengujian hipotesis lama tinggal $\left(\mathrm{X}_{4}\right)$ dengan partispasi masyarakat dalam program LMC (Y) menunjukkan nilai koefisien Rank Spearman $\left(\mathrm{r}_{\mathrm{s}}\right)$ yaitu sebesar $-0,192$ dan didapat nilai t hitung yaitu sebesar 1,660. Hal ini menunjukkan nilai $t$ hitung lebih kecil dari $t$ tabel pada taraf kepercayaan $\alpha(0,05$ dan 0,01$)$ artinya lama tinggal tidak mempunyai hubungan dengan tingkat partisipasi masyarakat dalam program LMC karena lama tinggal responden berkelompok pada rentang waktu 24-40 tahun sebanyak 40 orang $(54,05 \%)$. Hasil penelitian ini sejalan dengan hasil penelitian Yuliana (2017) yang menyatakan lama tinggal tidak berhubungan dengan tingkat partisipasi masyarakat dalam program.

Hasil pengujian hipotesis tingkat pengetahuan Program $\left(\mathrm{X}_{5}\right)$ dengan partispasi masyarakat dalam program LMC (Y) menunjukkan nilai koefisien Rank Spearman $\mathrm{r}_{\mathrm{s}}$ yaitu sebesar 0,108. Berdasarkan perhitungan didapat nilai $\mathrm{t}$ hitung yaitu sebesar 0,922 hal ini menunjukkan bahwa nilai t hitung lebih kecil dari t tabel pada taraf kepercayaan $\alpha(0,05$ dan 0,01$)$ artinya pengetahuan tentang program tidak mempunyai hubungan yang siginifikan dengan tingkat partisipasi masyarakat dalam program LMC di Desa Margasari Kecamatan Labuhan Maringgai Kabupaten Lampung Timur karena pengetahuan responden tentang program berkelompok pada klasifikasi cukup baik sebanyak 50 orang (67,56\%). Hasil penelitian ini tidak sejalan dengan hasil penelitian Hanif (2017) yang menyatakan pengetahuan tentang program berhubungan dengan tingkat partisipasi masyarakat dalam program. Tidak terdapatnya hubungan pengetahuan dengan partisipasi dikarenakan kurangnya sosialisasi dari pihak stakeholders kepada masyarakat mengenai program LMC.

Tabel 11. Hasil pengujian statistik faktor-faktor yang berhubungan dengan partisipasi (X) dengan partisipasi masyarakat dalam program LMC (Y)

\begin{tabular}{clccc}
\hline No & \multicolumn{1}{c}{ Variabel X } & Variabel Y & Nilai $_{\mathrm{s}}$ & t-hitung \\
\hline 1. & Usia & & $-0.048^{\mathrm{tn}}$ & $0,408^{\text {tn }}$ \\
2. & Sifat & & $0,282^{* *}$ & $2,494^{* *}$ \\
& Kosmopolit & & & \\
3. & Pendidikan & Partisipasi & $0,223^{*}$ & $1,941^{*}$ \\
& Formal & masyarakat & & \\
4. & Lama Tinggal & & $-0,192^{\text {tn }}$ & $1,660^{\text {tn }}$ \\
5. & Pengetahuan & & $0,108^{\text {tn }}$ & $0,922^{\text {tn }}$ \\
& Program & & & \\
\hline
\end{tabular}

Keterangan

** $\quad$ Nyata pada taraf kepercayaan $99 \%(\alpha=0,01)\left(t_{\text {tabel }}=2,379\right)$

* : Nyata pada taraf kepercayaan $95 \%(\alpha=0,05)\left(t_{\text {tabel }}=1,666\right)$

tn : Tidak nyata pada taraf kepercayaan $99 \%$ dan $95 \%$ 


\section{KESIMPULAN}

Tingkat partisipasi termasuk dalam klasifikasi sedang, hal ini dikarenakan kesadaran masyarakat untuk ikut serta dalam program masih kurang dan juga karena kurangnya sosialisasi dari stakeholders mengenai program. Sifat kosmopolit dan tingkat pendidikan formal berhubungan dengan tingkat partisipasi masyarakat sedangkan usia, lama tinggal, dan pengetahuan terhadap program tidak berhubungan dengan tingkat partisipasi masyarakat dalam program Lampung Mangrove Center.

\section{DAFTAR PUSTAKA}

Antika AY, Nikmatullah D, dan Prayitno RT. 2017. Tingkat partisipasi anggota P3A dalam program pengembangan jaringan irigasi (PJI) di Kelurahan Fajar Esuk Kecamatan Pringsewu Kabupaten Pringsewu. JIIA, 5 (3): 335-343. http://jurnal.fp.unila.ac.id/index.php /JIA/article/view/1647/1473. [20 Oktober 2018].

BPS [Badan Pusat Statistik] Lampung Timur. 2015. Lampung Timur dalam Angka tahun 2014. https://lampungtimurkab.bps.go.id/. [16 Maret 2016].

Ghufran M dan Kordi KM. 2012. Ekosistem Mangrove: potensi, fungsi, dan pengelolaan. Rineka Cipta. Jakarta.

Hanif M. 016. Partisipasi masyarakat dalam memberdayakan warga retardasi mental dengan model asanti emotan (studi kasus di sidoharjo jambon ponorogo). Jurnal Ilmu Sosial. 1 (1) 1-13. http://e-journal.ikippgrima diun.ac.id/index.php.gulawetah. [20 Oktober. 2018].

Nurmayasari I, Prasmatiwi FE, dan Saleh Y. 2017. Motivation and Participation of Food Burn Members in Lampung Province. Proceding of ISAE International Seminar. http://repository. lppm.unila.ac.id. [15 Januari 2019].

Murtiyanto N. 2011. Partisipasi Masyarakat. http://bagasaskara.wordpress.com/2011/10/12/ partispasi masyarakat teori ringkas. [8 September 2018].

Thania RS, Rangga KK, dan Viantimala B. 2017. Partisipasi petani dalam program upaya khusus peningkatan produksi padi, jagung, dan kedelai (UP2PJK) di Kecamatan Seputih Raman Kabupaten Lampung Tengah. JIAA, 5 (4): 446-452. http://jurnal.fp.unila.ac.id/index .php/JIA/article/view/1755. [12 November 2017].

Siegel S. 2011. Statistik Non Parametrik Untuk Ilmu-Ilmu Sosial, Terjemahan. PT. Gramedia. Jakarta.

Slamet Y. 1994. Pembangunan Masyarakat Berwawasan Partisipasi. Sebelas Maret University Press. Surakarta.

Sugiarto D, Siagian LT, Sunaryanto, Oetomo. 2003. Teknik Sampling. Gramedia Pustaka Utama. Jakarta.

Sugiono. 2009. Statistika untuk Penelitian. Alfabeta. Bandung.

Suroso. 2014. Faktor-Faktor yang Mempengaruhi Partisipasi Masyarakat Dalam Perencanaan Pembangunan di Desa Banjaran Kecamatan Driyorejo Kabupaten Gresik. Tesis. Universitas Brawijaya. Malang. https:// repository.ub.ac.id/155550. [19 Desember 2017].

Wicaksono dan Arya M. 2010. Analisis Tingkat Partisipasi Warga Dalam Tanggung Jawab Sosial Perusahaan. Skripsi. Institut Pertanian Bogor. Bogor. https://respository.ipb.ac.id/ jspui/bitstream/123456789/27290. [7 Mei 2017].

Widyanti E, Gitosaputro S, dan Yanfika H. 2015. Kebutuhan dan partisipasi masyarakat dalam program kemitraan dan bina lingkungan (PKBL) PTPN VII Unit Usaha Rejosari Kecamatan Natar Kabupaten Lampung Selatan. JIAA, 3 (2): 195-202. http://jurnal. fp.unila.ac.id/index.php/JIA/article/view/1039 1944. [31 Maret 2017].

Yuliana F dan Haswindy S. 2017. Partisipasi masyarakat dalam pengelolaan sampah pemukiman pada Kecamatan Tungkil Ilir Kabupaten Tanjung Jabung Barat. Jurnal Ilmu Lingkungan. Jurnal Ilmu Lingkungan. 15 (2) 96-111. http://ejournal.undip.ac.id/index. php/ilmulingkungan/article.download/14956.p df. [30 Oktober 2018]. 